\title{
The Effects Pandemic Covid-19 on Indonesia Foreign Trade
}

\author{
Misfi laili Rohmi ${ }^{1}$, Tiara Juliana Jaya ${ }^{2}$, and Nur Syamsiyah ${ }^{3}$ \\ ${ }_{1,3}$ IAIN Metro Lampung \\ ${ }^{2}$ UIN Maulana Malik Ibrahim Malang \\ Email Addres:

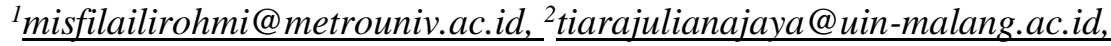 \\ 3nursyamsiyah@metrouniv.ac.id
}

\begin{abstract}
Indonesia is a developing country whose needs are exported from abroad. Therefore Indonesia needs foreign trade to fulfill goods that cannot be produced domestically or to distribute goods in which Indonesia has an absolute advantage in producing these goods. However, the policies are taken by the domestic government and Indonesia's foreign trading partner countries to limit the spread of the Covid-19 virus have an impact on the inflow of goods to and from abroad. Thus, this study intends to see how the Covid-19 pandemic has affected Indonesia's foreign trade by using the Paired Sample T-test, which observes conditions before and during/after a pandemic occurs. This study found that the Covid-19 pandemic had an impact on Indonesia's foreign trade from the aspect of oil and gas exports, imports of raw materials, and imports of Indonesian capital goods.
\end{abstract}

Key Word: Covid, International Trade, Import, Export.

Abstrak: Indonesia merupakan negara berkembang yang kebutuhannya di ekspor dari luar negeri. Karenanya Indonesia membutuhkan perdagangan luar negeri untuk memenuhi barang yang tidak bisa diproduksi di dalam negeri maupun untuk menyalurkan barang yang mana Indonesia memiliki keunggulan mutlak dalam memproduksi barang tersebut. Akan tetapi, kebijakan yang ditempuh pemerintah dalam negeri maupun negara mitra dagang luar negeri Indonesia untuk membatasi penyebaran virus Covid-19 jelas berdampak pada arus keluar masuk barang barang dari dan ke luar negeri. Dengan demikian, penelitian ini bermaksud melihat sejauh mana Pandemi Covid-19 memberikan pengaruh terhadap perdagangan luar negeri Indonesia dengan menggunakan uji Paired Sample T-test, yakni mengamati kondisi sebelum dan saat/setelah terjadi pandemic. Hasil penelitian ini menemukan fakta bahwa Pandemi Covid-19 berdampak pada perdagangan luar negeri Indonesia dari aspek ekspor migas, impor bahan mentah dan impor barang modal Indonesia Dan Pandemi Covid-19 tidak berdampak pada perdagangan luar negeri Indonesia dari aspek ekspor nonmigas dan impor barang konsumsi.

Kata Kunci Covid, Perdagangan Internasional, Impor, Ekspor. 


\section{INTRODUCTION}

What is happening in other countries can at least give an idea of the magnitude of the impact caused by this Covid pandemic. From the publication (Ministry of Finance, 2020), the COVID-19 pandemic has had a significant impact on the global economy. In the first quarter (Q1) 2020, economic growth in various countries experienced a decline in performance until the contraction in several countries. In China as the country of origin of COVID-19, Q1 economic growth contracted by $-6.8 \%$. Deep contraction also occurred in Europe $(-3.3 \%)$, including France $(-5.4 \%)$ which is one of the countries hardest hit by COVID-19. In Asia, Singapore recorded growth - 2.2\%, while South Korea (1.3\%), Indonesia $(3.0 \%)$, and Vietnam $(3.8 \%)$ were still able to record positive growth although much lower than the previous period. The United States (US) was also able to avoid an economic contraction in Q1, although it only grew by $0.3 \%$. The declining performance of world economic growth is largely a consequence of the extraordinary policies taken to suppress the transmission of COVID-19. Extreme activity restrictions and restrictions have kept global trading activity under pressure, as can be seen from the Baltic Dry Index which continues to be at a very low level. The manufacturing sector was also severely affected, as seen from the Manufacturing Purchasing Manager Index (PMI) at the world level and in various countries, which contracted even more than the contraction during the global financial crisis period. China's PMI, which briefly rebounded to levels above 50 (indicating positive growth) in March, fell back below 50 levels in April although not as deep as other countries. As the initial country of COVID-19 transmission that has taken extreme measures such as a lockdown since February, the pattern of suppressing COVID-19 and China's economic recovery is running earlier than most other countries.

The decline in the level of global economic demand made commodity prices also continue to weaken. The deepest decline occurred in crude oil, which was also affected by the issue of the Saudi Arabia-Russia price war and storage capacity. As of April, world crude oil prices fell more than $65 \%$ (ytd). The decline in oil prices has an impact on other energy commodities such as coal. Metal commodity prices also weakened in line with expectations of reduced industrial activity. Prices of food and agricultural commodities are relatively more stable with a slight upward trend in recent times driven by tight global supply. The IMF projects that crude oil prices in 2020 will be below the 2019 average. The projected weak commodity prices in the future could cause commodity exporters to experience pressure on their financing and business activities Ministry of Finance (2020).

COVID-19 is spreading at a rate that can cause fear for international trade (Gormsen and Koijen, 2020). Similarly, Indonesia's economy is devastated by COVID 19. Indonesia's economic growth is expected to decline at $2.1 \%-3.5 \%$ in 2020 , and it is predicted that in 2021-2022 it will return to an average of 5.4\% when aggregate demand has improved (Muhyiddin, 2020). According to Sri Mulyani in the Press conference "Measures to Strengthen Social Protection and Economic Stimulus Facing the Impact of Covid-19," stated that Covid19 would have an impact on several sectors, namely. (1) The household sector is health problems, loss of income, decrease in purchasing power of the community. (2) MSME sector, i.e., MSMEs cannot run their businesses and the increase in NPL credit for MSMEs. (3) Co-ordination sectors such as manufacturing, transportation, accommodation, 
and trade industries will be disrupted. (4) The financial sector will experience liquidity, depreciation, and capital flight problems.

Indonesia is based on epidemiological, resource, economic, social and cultural, security, and the magnitude of the threat of effectiveness. President Joko Widodo establishes large-scale social restrictions (PSBB) that are considered to result in economic and trade problems (Sari, 2020). This social or physical distancing has an influence on a decrease in overall economic activity ((Iskandar et al., 2020). The rapid spread of the virus and the challenge to identify forces the international world to think quickly and appropriately to take public policy. As a country with an open economy, Indonesia cannot be separated from international trade activities (Thirafi, 2020).

In terms of Indonesia's foreign trade, the lockdown policy implemented by the destination country and exports or the country of import origin impacts the disruption of Indonesia's import-export activities. The following is a graph of Indonesia's export growth during the period 2018-2021.

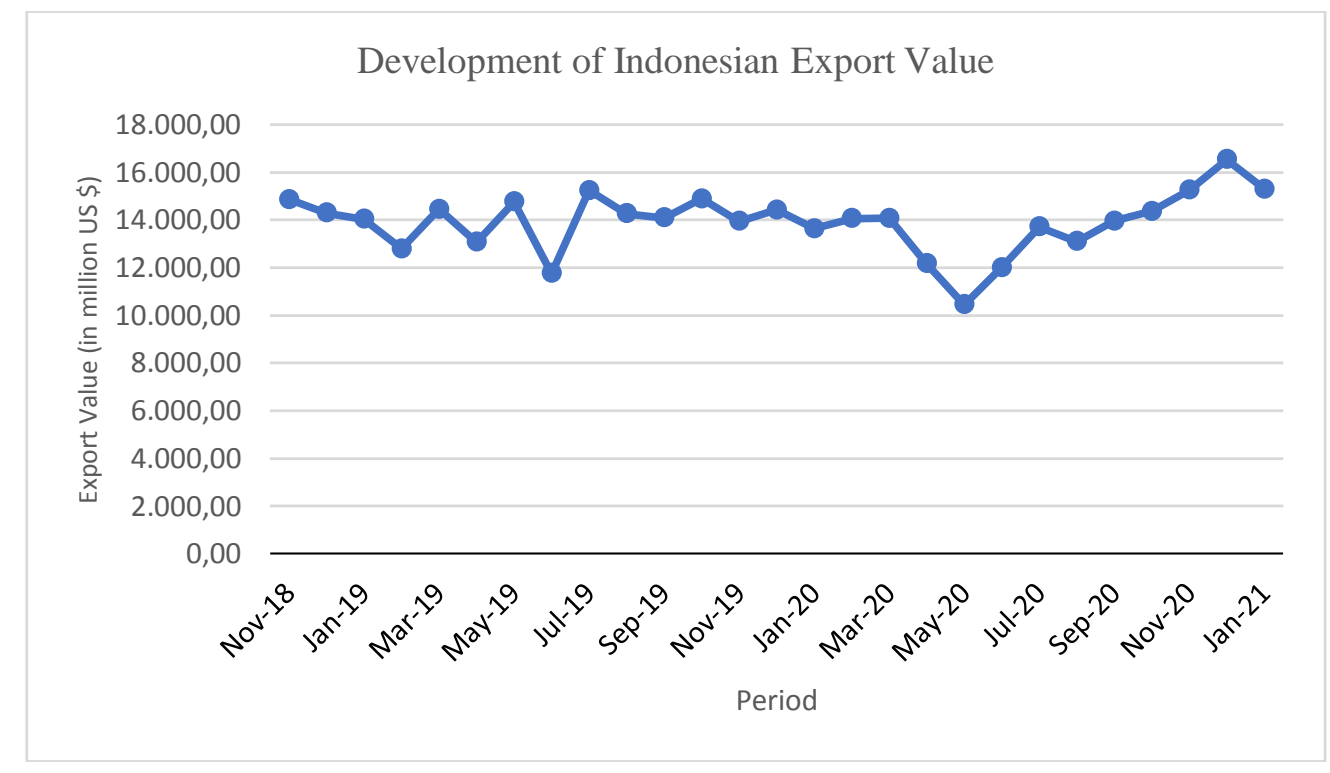

Figure 1. Development of Indonesian Export Value

The figure above shows that the value of exports is experiencing a volatile trend; a reasonably sharp decline occurred in March 2020 - May 2020. This is suspected because of the pandemic outbreak that hit the world, so that it has implications in the foreign trade sector of Indonesia.

(Budiyanti, 2020) in his research, suggests that non-oil and gas exports and non-oil and gas imports decreased in January 2020 when compared to the previous month. This decrease occurred to most major destination countries, China, which reached USD 211.9 million or down $9.15 \%$. Meanwhile, the total value of non-oil and gas imports during January 2020 was USD 9,670 million or decreased by USD 313.5 million or decreased by $3.14 \%$ compared to December 2019. The decrease was influenced by the decreasing value 
of non-oil and gas imports from several major countries, including China, from USD 4.07 billion to USD 3.94 billion or down $3.08 \%$.

(Sari, 2020) stated that during the Covid-19 pandemic, Indonesia's export and import activities were disrupted (observation using SITC code). In January 2020, Indonesia's total monthly exports were 118.89 . This figure rose by 4.35 compared to December 2019. In February 2020, Indonesia's monthly export value was 125.22 . This is an increase of 6.40 compared to January 2020. While in March 2020 amounted to 118.82. This figure decreased by 6.40 compared to February 2020 .

In terms of imports, it is seen on the chart that the value of Indonesia's imports throughout 2019-2020 is also experiencing a volatile trend. In March-May 2020, Indonesian imports' value decreased quite sharply, allegedly due to the official announcement of positive cases of Covid-19 for the first time on March 02, 2020. Indonesia's largest import country, China, which imposed a lockdown caused a limited number of commodities before the pandemic.

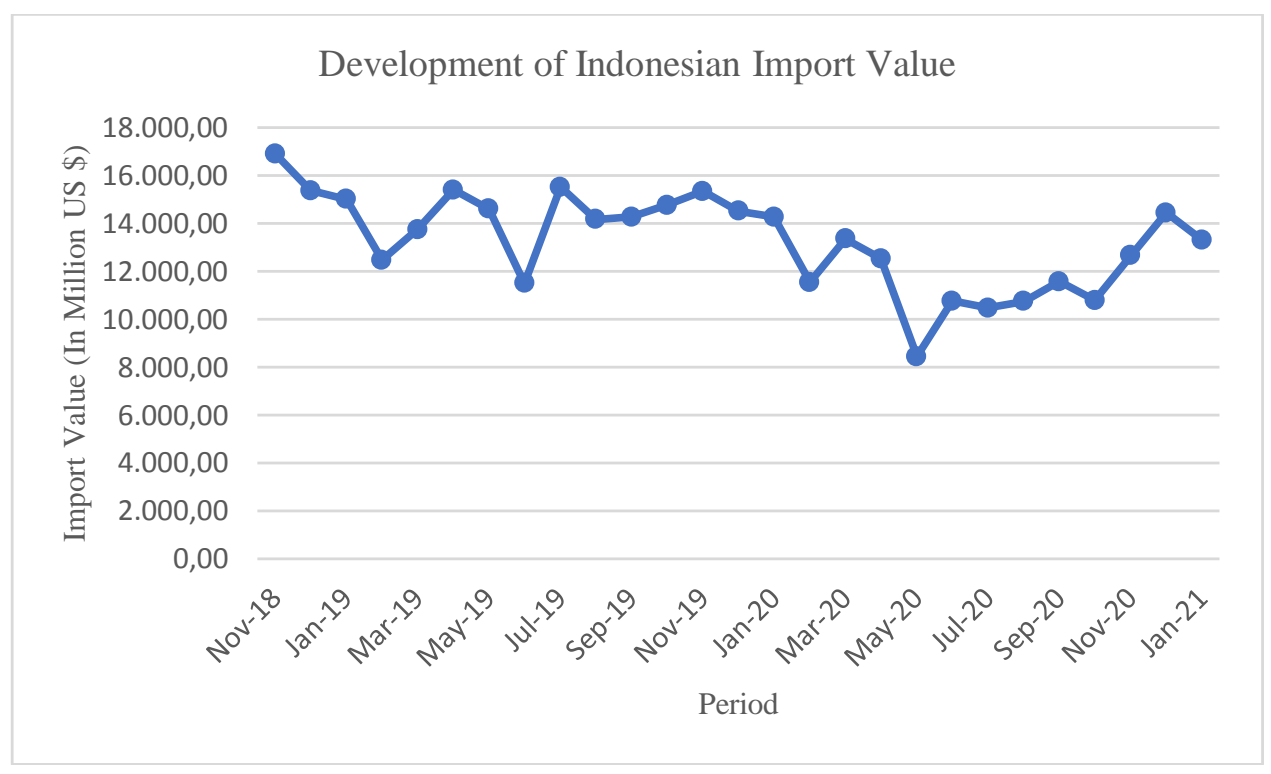

Figure 2. Development of Indonesian Import Value

This study intends to see how the impact of the Covid-19 pandemic on aspects of Indonesia's international trade before and after the pandemic. The data was taken until the Ministry of Trade's last release (January 2021), when this research was compiled.

\section{THEORITICAL REVIEW}

International Trade. Foreign trade often arises because of differences in the prices of goods in different countries. Prices are determined by production costs consisting of wages, capital costs, land rent, and raw material costs, as well as efficiency in the production 
process. In addition to price differences, other factors that can cause international trade are differences in natural resources and production factors that exist in a country. Each country has different natural resources so it will produce different goods. However, because people's needs are very diverse and the state can't meet all the needs of its people, this causes international trade to meet the needs within a country (Pradeksa et al., 2016).

The development of international trade in each country cannot be separated from things that are and will take place in global economic activities. The flow of economic globalization and free trade provides opportunities as well as obstacles to trade activities that spread to the Indonesian economy. In general, the Indonesian state carries out trading activities in the form of exports and imports from and to various countries in the world (Wahyu Setianto, 2014).

International trade involves the transfer of ownership of goods or services that cross the borders of the state territory; in this case, the activity is experiencing constraints due to the Covid 19 Pandemic that hit the world, because the world economy is in crisis and millions of people around the world depend on international trade for food security and livelihoods (Pinshi, 2020). The COVID-19 pandemic, established by the United Nations, affects transportation, tourism, employment, health, and other sectors. The "lockdown" policy adopted by various countries prevents the further spread of covid-19, resulting in hampered economic activity and pressure on world economic growth in the future, including its development (Susilawati et al., 2020). A country establishes international trade relations due to technological differences, differences in natural resources wealth, differences in tastes, climate differences, and increased profits. To meet the country's needs, the government will follow international trade (Tobing and Panday, 2020).

(Safitriani, 2014) explains that one of the economic activities that cannot be separated from international trade is the activity of capital flows, both in and out of a country. When international trade activities occur in the form of export and import activities, it is likely that there will be a transfer of production factors from the exporting country to the importing country due to differences in costs in the international trade process.

Export. Exports are helpful to reduce the impact of the fragile domestic market by widening the coverage of the target market to the global market (Bakari \& Mabrouki, 2017). Exports also help gain knowledge on how to market products in foreign markets. This study uses data on Indonesia's oil and gas exports and non-oil and gas exports in 2019 - early 2021, which are sourced from data from the Indonesian Ministry of Trade combined with data from BPS. The oil and gas sector consists of oil and natural gas, and the non-oil and gas sector consists of the agricultural, plantation, forestry, industrial, handicraft, and service sectors (Mejaya et al., 2016).

From a macroeconomic perspective, an export-based economy has several advantages including: (1) Export activities will generate cash inflows in the form of foreign currency as payment for products sold abroad. The foreign exchange received will certainly increase the foreign exchange reserves of the exporting country, which in turn can strengthen the country's economic fundamentals. (2) Export activities will be able to absorb a lot of workers, especially for non-oil and gas exports. This of course is very suitable for Indonesia, which has a large workforce. (3) Export-based countries are to facilitate the achievement of 
the goal of economic independence. Countries that depend on their national needs by importing goods from outside will be easily affected by economic turmoil (Wardhana, 2014)

Import. Globally about 20 percent of manufactured products are produced in China, and therefore, with the rise of COVID 19, many countries face significant problems (Hasanat et al., 2020). Not only China but other countries where their products are imported are equally hampered. On the other hand, imports are an activity in which a country enters goods or services from another country. Imports are an indicator of a country's inability to meet its own needs (Bakari \& Mabrouki, 2017). All countries conducting international trade activities will have a trade balance that records export-import activities therein. This study uses data on imports of Indonesian capital goods, raw goods and consumer goods in $2019-$ early 2021 sourced from data from the Ministry of Trade of the Republic of Indonesia which is combined with data from BPS.

\section{Conceptual Framework}

The frame of mind in this study is as follows

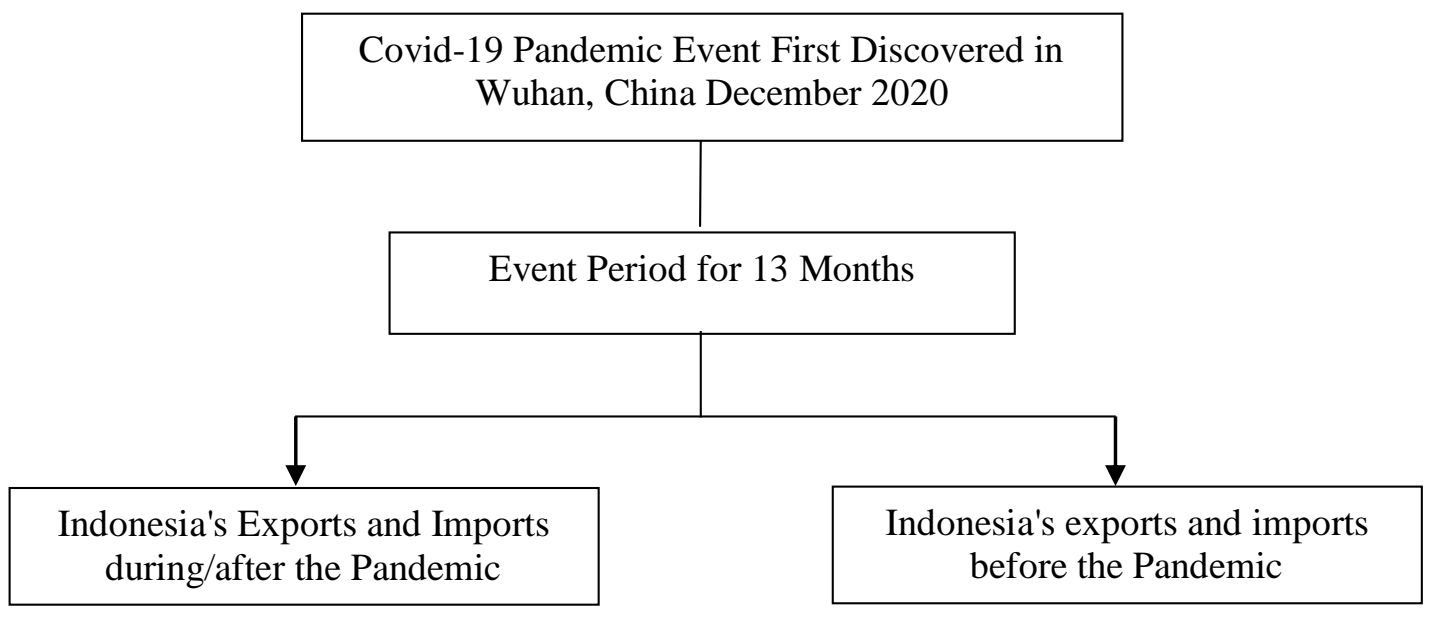

Figure 3. Conceptual Framework

\section{METHOD}

This research is included in quantitative analysis using paired sample t-test. The paired sample t-test was conducted to determine the difference in the average of 2 (two) groups of samples in pairs, but the treatment obtained was different (Nuryadi et al., 2017). This study was conducted to look at Indonesia's foreign trade by comparing the conditions before and after the pandemic until the last month released by the Ministry of Trade Pandemic. Time series data is processed using SPSS 24.

Data analysis in this study used parametric statistical analysis with paired sample ttest. As a rule in parametric statistics, the data must be normally distributed. Thus, before analyzing the data with a different test, the normality test of the data will be carried out first. The basis for decision-making in this test is determined by looking at the significant value. 
If the value of sig. $>0.05$ then the data is normally distributed, and vice versa if the value of sig. $<0.05$ then the data is not normally distributed (Putri and suhadak, 2018).

The paired sample t-test was carried out to find out the difference in the average of 2 (two) paired sample groups, but the treatment they got was different (Nuryadi et al., 2017). The data used is secondary data in the form of time-series data. The data is sourced from the Ministry of Finance and the Central Statistics Agency (BPS). The data is then processed using SPSS. The paired t-test is a parametric test that is by the purpose of this study, namely to analyze whether there are differences in paired samples (Putri \& suhadak, 2018). The formula for the paired t-difference test is as follows:

$$
t=\frac{\text { first sample average }- \text { second sample average }}{\text { Standard error of the difference between the two samples }}
$$

The decision making criteria in this test are as follows standard error of the difference between the two samples

1) Ho is accepted if: $t$ count $\leq t$ table or Sig. $>0.05$.

2) Ha is accepted if: $t$ count $>t$ table or Sig. $\leq 0.05$.

The observed time is 13 months before discovering the coronavirus for the first time in December 2019, namely November 2018-November 2019, and 13 months after that, namely January 2020-January 2021. The retrieval of this period is intended to obtain updated data until the time of this study.

The observation moon can be seen from the following table

Table 1. Month of Observation Before and After Covid 19

\begin{tabular}{lc}
\hline \multicolumn{2}{l}{ Month of Observation Before Covid 19 } \\
\hline Nov 2018 & -13 \\
\hline Dec 2018 & -12 \\
\hline Jan 2019 & -11 \\
\hline Feb 2019 & -10 \\
\hline Marc 2019 & -9 \\
\hline Apr 2019 & -8 \\
\hline May 2019 & -7 \\
\hline Jun 2019 & -6 \\
\hline Jul 2019 & -5 \\
\hline Agust 2019 & -4 \\
\hline Sept 2019 & -3 \\
\hline Oct 2019 & -2 \\
\hline Nov 2019 & -1 \\
\hline
\end{tabular}

\begin{tabular}{lc}
\hline \multicolumn{2}{c}{ Month of Observation After Covid 19 } \\
\hline Dec 2019 & 0 \\
\hline Jan 2020 & +1 \\
\hline Feb 2020 & +2 \\
\hline March 2020 & +3 \\
\hline Apr 2020 & +4 \\
\hline May 2020 & +5 \\
\hline Jun 2020 & +6 \\
\hline Jul 2020 & +7 \\
\hline Agust 2020 & +8 \\
\hline Sep 2020 & +9 \\
\hline Oct 2020 & +10 \\
\hline Nov 20 & +11 \\
\hline Dec 2020 & +12 \\
\hline Jan 2021 & +13 \\
\hline
\end{tabular}




\section{RESULTS AND DISCUSSION}

The Effects of the Covid-19 Pandemic on Indonesia's Oil and Gas Exports. Before the test paired sample t-test, first conducted a trial against the normality of the data as the primary condition of parametric statistics. Here are the results of the normality test with SPSS of Indonesia's oil and gas exports before and after the Covid-19 pandemic Here are the results of normality tests on Indonesian foreign trade variables.

Table 2. Tests of Normality

\begin{tabular}{|c|c|c|c|c|c|c|}
\hline \multicolumn{7}{|c|}{ Tests of Normality } \\
\hline & \multicolumn{3}{|c|}{ Kolmogorov-Smirnov ${ }^{\mathrm{a}}$} & \multicolumn{3}{|c|}{ Shapiro-Wilk } \\
\hline & Statistic & $\mathrm{df}$ & Sig. & Statistic & df & Sig. \\
\hline $\begin{array}{l}\text { Oil and gas exports before } \\
\text { the pandemic }\end{array}$ & .162 & 13 & $.200^{*}$ & .930 & 13 & .338 \\
\hline $\begin{array}{l}\text { Oil and gas exports after } \\
\text { the pandemic }\end{array}$ & .194 & 13 & .193 & .900 & 13 & .135 \\
\hline $\begin{array}{l}\text { Non-oil and gas exports } \\
\text { before the pandemic }\end{array}$ & .174 & 13 & $.200^{*}$ & .917 & 13 & .230 \\
\hline $\begin{array}{l}\text { Non-oil and gas exports } \\
\text { after the pandemic }\end{array}$ & .134 & 13 & $.200^{*}$ & .971 & 13 & .903 \\
\hline $\begin{array}{l}\text { Imports of consumption } \\
\text { before the pandemic }\end{array}$ & .208 & 13 & .127 & .911 & 13 & .190 \\
\hline $\begin{array}{l}\text { Imports of consumption } \\
\text { after the pandemic }\end{array}$ & .085 & 13 & $.200^{*}$ & .978 & 13 & .971 \\
\hline $\begin{array}{l}\text { Import of raw materials } \\
\text { before the pandemic }\end{array}$ & .160 & 13 & $.200^{*}$ & .954 & 13 & .655 \\
\hline $\begin{array}{l}\text { Import of raw materials } \\
\text { after the pandemic }\end{array}$ & .123 & 13 & $.200^{*}$ & .958 & 13 & .717 \\
\hline $\begin{array}{l}\text { import of capital goods } \\
\text { before the pandemic }\end{array}$ & .155 & 13 & $.200^{*}$ & .912 & 13 & .198 \\
\hline $\begin{array}{l}\text { import of capital goods } \\
\text { after the pandemic }\end{array}$ & .194 & 13 & .192 & .942 & 13 & .489 \\
\hline
\end{tabular}

The normality test using Shapiro-Wilk obtained the significance value of Indonesian foreign trade variables both before and after the pandemic is greater than the alpha value specified (0.05). It can be concluded that all data is usually distributed. Furthermore, after the normality assumption is fulfilled, a paired sample t-test is conducted with the following results. 
Table 3. Paired Samples Test

\begin{tabular}{|c|c|c|c|c|c|c|c|c|c|}
\hline \multirow{2}{*}{\multicolumn{2}{|c|}{ Paired Differences }} & \multirow{3}{*}{$\frac{\text { Mean }}{344,83462}$} & \multirow{3}{*}{$\begin{array}{c}\begin{array}{c}\text { Std. } \\
\text { Deviation }\end{array} \\
296,20101\end{array}$} & \multirow{3}{*}{$\begin{array}{c}\begin{array}{c}\text { Std. Error } \\
\text { Mean }\end{array} \\
82,15138\end{array}$} & \multicolumn{2}{|c|}{$\begin{array}{l}\text { 95\% Confidence Interval } \\
\text { of the Difference }\end{array}$} & \multirow[b]{3}{*}{4,198} & \multirow[b]{3}{*}{12} & \multirow[b]{3}{*}{0,001} \\
\hline & & & & & Lower & Upper & & & \\
\hline Pair 1 & $\begin{array}{l}\text { Oil and gas } \\
\text { exports before } \\
\text { the pandemic - } \\
\text { Oil and gas } \\
\text { exports after the } \\
\text { pandemic }\end{array}$ & & & & 165,84214 & 523,82709 & & & \\
\hline Pair 1 & $\begin{array}{l}\text { Non-oil and gas } \\
\text { exports before } \\
\text { the pandemic - } \\
\text { Non-oil and gas } \\
\text { exports after the } \\
\text { pandemic }\end{array}$ & $-52,84615$ & 1388,45798 & 385,08896 & $-891,88291$ & 786,19060 & $-0,137$ & 12 & 0,893 \\
\hline Pair 1 & $\begin{array}{l}\text { Imports of } \\
\text { consumption } \\
\text { before the } \\
\text { pandemic - } \\
\text { Imports of } \\
\text { consumption } \\
\text { setelah the } \\
\text { pandemic }\end{array}$ & 124,28077 & 263,16326 & 72,98836 & $-34,74720$ & 283,30873 & 1,703 & 12 & 0,114 \\
\hline Pair 1 & $\begin{array}{l}\text { Import of raw } \\
\text { materials before } \\
\text { the pandemic - } \\
\text { Import of raw } \\
\text { materials before } \\
\text { the pandemic }\end{array}$ & 2071,26615 & 1326,12542 & 367,80102 & 1269,89658 & 2872,63573 & 5,631 & 12 & 0,000 \\
\hline Pair 1 & $\begin{array}{l}\text { imports of } \\
\text { capital goods } \\
\text { before the } \\
\text { pandemic - } \\
\text { imports of } \\
\text { capital goods } \\
\text { after the } \\
\text { pandemic }\end{array}$ & 431,70231 & 303,13803 & 84,07536 & 248,51783 & 614,88679 & 5,135 & 12 & 0,000 \\
\hline
\end{tabular}

Table 3 is the most crucial output because it answers research questions about whether or not there is an average difference in conditions before the pandemic and after the pandemic based on the value of sig. (2-tailed) $<0.05$, then it can be concluded there is a difference in average and vice (Santoso, 2016). From the table, we can see there are three variables that value sig. (2-tailed) < 0.05 , i.e., the value of oil and gas exports, imports of raw materials, and imports of capital goods. Thus, it can be concluded that the Covid-19 pandemic affects oil and gas exports, imports of raw materials, and imports of Indonesian capital goods.

This study's results are in line with research conducted by Thirafi (2020), where negative trends experienced in Indonesia's trade balance due to the Covid-19 pandemic, starting from March 2020 and reaching its peak in May 2020. According to a report by the Ministry of Finance (2020), the Covid-19 pandemic has had a significant impact on the economy globally. The decline in global economic demand has also weakened commodity prices. The issue of a price war between Saudi Arabia and Russia led to a decrease in crude oil commodities. The cost of world crude oil fell more than $65 \%$, as the drop in oil prices influenced other energy commodities such as coal. Metal commodity prices also weakened 
as expectations of reduced industrial activity eased. The IMF projects crude oil prices in 2020 will be below the 2019 average. The projection of weak commodity prices in the future may cause commodity exporters to experience pressure on financing and business activity. Ministry of Finance Report (2020), cumulatively viewed from January to April 2020, imports of raw/auxiliary materials and capital goods decreased by $7.3 \%$ (yoy) and $14 \%$ (yoy) respectively.

\section{Effects of the Covid-19 Pandemic on Oil and Gas Exports, Imports of Raw Materials and} Imports of Indonesian Capital Goods. Meanwhile, the significance of variable non-oil and gas exports and imports of consumer goods shows a figure more significant than the alpha value, so it can be concluded that there is no influence of the Covid-19 pandemic non-oil and gas exports and imports of Indonesian consumer goods. This is in line with research (Tobing \& Panday, 2020), which found similar results in which from observations for 9 (nine) months on Indonesia's non-oil and gas exports before and after the pandemic also found no difference, which means the Covid-19 pandemic does not affect Indonesia's nonoil and gas exports.

The following is a graph of the development of Indonesia's non-oil and gas exports during the Covid-19 pandemic

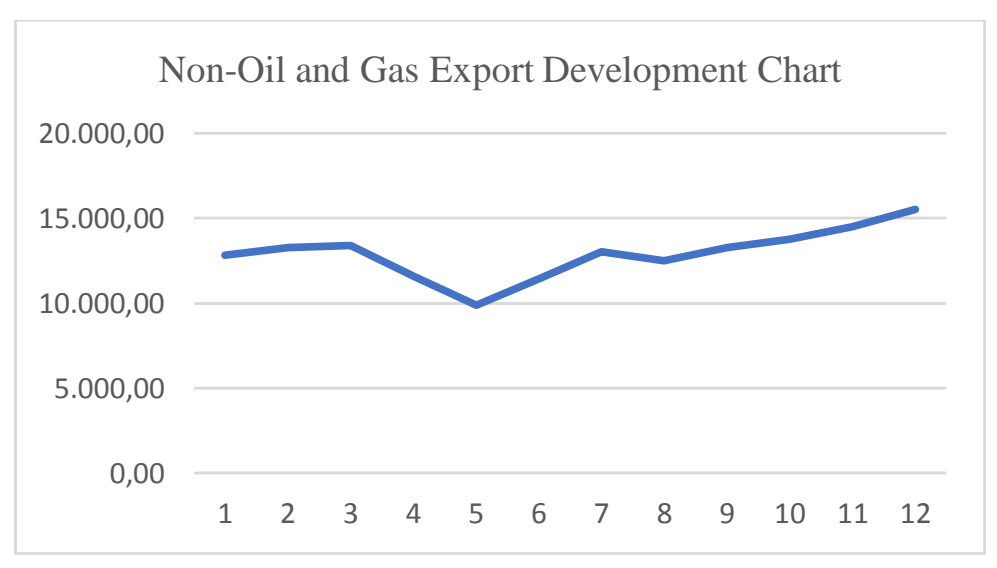

Figure 4 Non-Oil and Gas Export Development Chart Source : Data processed

From the graph, we can see that at the beginning of the pandemic, Indonesia's non-oil and gas exports had experienced a sharp decline, but in the following months Indonesia's non-oil and gas exports again showed an increase.

In terms of imports of consumer goods, this study is in line with research Hobbs (2020), which states that the Covid Pandemic causes shocks on the demand side of consumer goods, panic buying and hoarding by consumers so that there is a run out of stock of consumer goods in the short term. Although the Covid pandemic has lowered the competitiveness of various sectors of the economy, it has no impact on Canada's food and agricultural export sectors. Canada is a significant exporter of foodstuffs and agriculture. That means that the importing countries of food and agriculture continue to import because they have to meet domestic needs due to the emptiness of food stocks caused by the Covid- 
19 pandemic. Canada is still able to provide food supplies to surrounding countries. This illustrates that during the Pandemic, the need for consumption materials actually increased in order to maintain individual survival so that in general the Covid-19 Pandemic actually increased the demand for consumer goods.

Covid-19 is known to have been in Indonesia on March 2, 2020, when it was published two residents of Depok, West Java was affected by this virus. Since then, Covid-19 has spread rapidly across the archipelago with the number of infected cases and deaths continuing to increase. To deal with this, the government issued various policies, including the Large-Scale Social Restriction (PSBB) policy through a Government Regulation (PP) on March 31, 2020. At the beginning of the handling of the Covid-19 pandemic, the government's attention was mainly focused on handling health aspects. However, over time, the impact of the pandemic and social restriction policies have disrupted all sectors of life. For this reason, in addition to continuing to address the health aspect, various policies have been issued to overcome the impact of the pandemic on businesses experiencing a decline in production activities and people suffering from declining incomes and purchasing power (Ahmad Suryana, I Wayan Rusastra, Tahlim Sudaryanto, Sehat, 2020)

The government must choose a policy from a 2-way path in dealing with this pandemic (Yamali \& Putri, 2020). The government must look at substantive policies and focus on policies that regulate the economy. The two policies were carried out simultaneously which resulted in the ineffective implementation of these policies. In addition to the ineffective implementation of the policies that have been made, these policies also make coordination between the central government and local governments not well established. The objectives to be achieved from the policy are breaking the chain of the virus's spread and economic improvement has not yet been achieved it tends to get worse (Muhyiddin, 2020)

The COVID-19 pandemic has forced the Indonesian government to issue regulations/policies related to its handling. The regulations/policies referred to include 4 Presidential Decrees, 2 Presidential Regulations, 1 Government Regulation, 1 Presidential Instruction, and 1 Government Regulation in place of Law. The regulations that have been made are alternative solutions to problems that can be seen from the health, bureaucracy, political and financial aspects of the Indonesian state as a result of the COVID-19 pandemic. One of the Indonesian state finances depends on the foreign trade sector, in this case, exports and imports. Thus, the government should make policies that can boost the foreign trade sector, for example by providing subsidies to exporters as well as suppressing taxes and special import duties on consumer goods, considering that during the Covid pandemic, people can get panic buying at any time so that the market is over-demanded for goods. consumption.

Nine regulations that have been issued by the government are the basis for the allocation, distribution, and stabilization policies that can be carried out. The first step is that the government is obliged to allocate qualified inputs and resources to its policy orientation (Allocation Policy), namely to the new vulnerable groups affected by Covid-19, including business groups that require mass crowds, groups of casual daily workers, street vendors, businessmen. workers affected by layoffs, farmers, the poor, and so on. However, we know that foreign trade is a business group that requires mass crowds both as exporters/importers and the wider community as a market share. 
These Covid-19 externalities have weakened their opportunities to generate daily income, caused massive layoffs of workers, and weakened company finances. This incident will experience an increase in numbers that continue to increase if this pandemic lasts long. In addition, the "stay at home" appeal to the community will result in a significant decrease in people's income from their routines, very limited economic activity, and other influences that follow.

\section{CONCLUSION}

The conclusions of this study are as follows. (1) The Covid-19 pandemic impacted Indonesia's foreign trade in terms of oil and gas exports, imports of raw materials, and Indonesian capital goods imports. (2) The Covid-19 pandemic has no impact on Indonesia's foreign trade in terms of non-oil and gas exports and imports of consumer goods.

The recommendation of this study are as follows. (1) Reduce or limit export bans on certain commodities such as oil and gas exports that are severely affected by pandemics. (2) 2) Simplify and reduce import restrictions on the types of imported goods affected by the pandemic, such as importing raw materials and importing capital goods. (3) Provide convenience, for example, by providing subsidies for exporter companies and importers affected by the pandemic

\section{REFERENCES}

Ahmad Suryana, I Wayan Rusastra, Tahlim Sudaryanto, Sehat, M. P. (2020). Dampak Pandemi Covid-19.

Bakari, S., and Mabrouki, M. (2017). Impact of Exports and Imports on Economic Growth: New Evidence From Panama. Journal of Smart Economic Growth, 2(1), 67-79.

Budiyanti, E. (2020). Dampak Virus Corona Terhadap Sektor Perdagangan Dan. Pusat Penelitian Badan Keahlian DPR RI, XXI(4), 19-24.

Gormsen, N. J., and Koijen, R. S. J. (2020). Coronavirus: Impact on stock prices and growth expectations. Review of Asset Pricing Studies, 10(4), 574-597. https://doi.org/10.1093/rapstu/raaa013.

Hasanat, M. W., Hoque, A., Shikha, F. A., Anwar, M., Hamid, A. B. A., and Tat, H. H. (2020). The impact of coronavirus on business continuity planning. Asian Journal of Multidisciplinary Studies, 3(1), 85-90.

Hobbs, J. E. (2020). Food supply chains during the COVID-19 pandemic. Canadian Journal of Agricultural Economics, 68(2), 171-176. https://doi.org/10.1111/cjag.12237.

Iskandar, A., Possumah, B. T., dan Aqbar, K. (2020). Peran Ekonomi dan Keuangan Sosial Islam saat Pandemi Covid-19. SALAM: Jurnal Sosial Dan Budaya Syar-I, 7(7). https://doi.org/10.15408/sjsbs.v7i7.15544.

Kementerian Keuangan. (2020). Laporan Ekonomi dan Keuangan.

Lenzen, M., Li, M., Malik, A., Pomponi, F., Sun, Y. Y., Wiedmann, T., Faturay, F., Fry, J., Gallego, B., Geschke, A., Gómez-Paredes, J., Kanemoto, K., Kenway, S., Nansai, K., Prokopenko, M., Wakiyama, T., Wang, Y., and Yousefzadeh, M. (2020). Global Socio-Economic Losses and Environmental Gains From The Coronavirus Pandemic. PLoS ONE, 15(7), 1-13. https://doi.org/10.1371/journal.pone.0235654. 
Mejaya, A., Fanani, D., dan Mawardi, M. (2016). Pengaruh Produksi, Harga Internasional, Dan Nilai Tukar Terhadap Volume Ekspor (Studi pada Ekspor Global Teh Indonesia Periode Tahun 2010-2013). Jurnal Administrasi Bisnis S1 Universitas Brawijaya, $35(2), 20-29$.

Muhyiddin. (2020). Covid-19, New Normal dan Perencanaan Pembangunan di Indonesia. The Indonesian Journal of Development Planning, IV(2), 240-252. https://doi.org/10.1016/j.cpha.2021.01.002.

Nuryadi, N., Astuti, T. D., Utami, E. S., dan Budiantara, M. (2017). Dasar-Dasar Statistika Penelitian. Sibuku Media.

Pinshi, C. (2020). What impact does COVID-19 have on the Congolese economy and international trade?

Pradeksa, Y., Darwanto, D. H., dan Masyhuri, M. (2016). Faktor-Faktor Yang Mempengaruhi Impor Gandum Indonesia. Agro Ekonomi, 25(1). https://doi.org/10.22146/agroekonomi.17381.

Putri, A. B., dan suhadak. (2018). Perang Dagang Amerika Serikat Dan China ( Studi pada Badan Pusat Statistik Periode September 2017- September 2018 ). Jurnal Administrasi Bisnis S1 Universitas Brawijaya, 71(1), 81-90.

Safitriani, S. (2014). Perdagangan Internasional Dan Foreign Direct Investment Di Indonesia. Buletin Ilmiah Litbang Perdagangan, 8(1), 93-116. https://doi.org/10.30908/bilp.v8i1.89.

Santoso, S. (2016). Panduan Lengkap SPSS Versi 23 (Pertama). PT. Elex Media Komputindo.

Sari, D. (2020). Fenomena Ekonomi Dan Perdagangan Indonesia Di Masa Pandemi Corona Virus Disease-19 ( Covid-19 ). Jurnal Akuntansi Dan Investasi, 4(1), 81-93.

Susilawati, S., Falefi, R., and Purwoko, A. (2020). Impact of COVID-19's Pandemic on the Economy of Indonesia. Budapest International Research and Critics Institute (BIRCIJournal): Humanities and Social Sciences, 3(2), 1147-1156. https://doi.org/10.33258/birci.v3i2.954.

Thirafi, L. (2020). Dua Dekade Terakhir Neraca Perdagangan Indonesia. Jurnal Ekonomi Dan Pendidikan, 17(2), 70-82. https://doi.org/10.21831/jep.v17i2.34616.

Tobing, G. M., dan Panday, R. (2020). Uji Beda Nilai Ekspor Nonmigas Di Indonesia Sebelum Dan Saat Terjadinya Pandemi Virus Corona. December.

Wahyu Setianto. (2014). Analisis Faktor-Faktor Yang Mempengaruhi Ekspor Tekstil Indonesia Periode 2007-2011. Economics Development Analysis Journal, 3(1), 124 134. https://doi.org/10.15294/edaj.v3i1.3525.

Yamali, F. R., dan Putri, R. N. (2020). Dampak Covid-19 Terhadap Ekonomi Indonesia. Ekonomis: Journal of Economics and Business, 4(2), 384. https://doi.org/10.33087/ekonomis.v4i2.179. 